\title{
CONTRIBUTION TO QUALITY OF AIR TRAFFIC DUE TO REDUCTION OF GASEOUS EMISSIONS
}

\author{
ALENA PAULIKOVÁ, MELICHAR KOPAS
}

\section{INTRODUCTION}

Sustainable development of a comfortable travel by planes has to meet also requirements concerning quality of living environment. This aspect includes questions concerning reduction of gaseous emissions arising from everyday intensive worldwide air traffic, which is winding our planet like an invisible spider web. Both authors of this paper often cooperate professionally in the area of environmental impacts of all traffic kinds including the air traffic environmental aspects (Pauliková and Kopas, 2011).

Aircraft jet engines are power units applied in the most of transport and military planes. They had been introduced into a current operation during the 50-ties of the last century, however technical development of the turbo-jet engines started in the time period of the World War II.

A brief description of the jet engine functioning is as follows (Kocáb and Adamec, 2000): air entering through an annular (ring-shaped) air intake at the front of the engine passes into a compressor. The compressor (mostly it is a multi-stage axial-flow compressor) sucks and compresses the incoming air, which is entering combustion chambers (that are located around the periphery of the engine) at high pressure and temperature. The compressed air is mixed with a fuel in the combustion chambers and this mixture is burning continuously during the whole engine operation after an initiatory ignition, i.e. after the start-up sequence. Product of the burning process is a flow of hot gases that are flowing into the turbine (it is multi-stage axial-flow turbine usually). The turbine is connected with the compressor by means of a common shaft, which is driven thanks to the kinetic energy of expanding hot gases. After expansion in the turbine, the flow of hot gases escapes at high velocity, (i.e. at high kinetic energy), through the exhaust nozzle, thus providing the forward thrust for the airplane. There is applied in this way the well-known "action-reaction" physical principle.

\section{TYPES OF TURBO-JET ENGINES}

Taking into consideration the historical development, there were designed the turbojet engines firstly, i.e. the jet engines without a bypass, Figure 1. 
Next progress introduced the by-pass engines with a low bypass ratio, Figure 2 and the by-pass engines with a high bypass ratio, which are called also the turbofan engines or the fan-type engines, Figure 3.

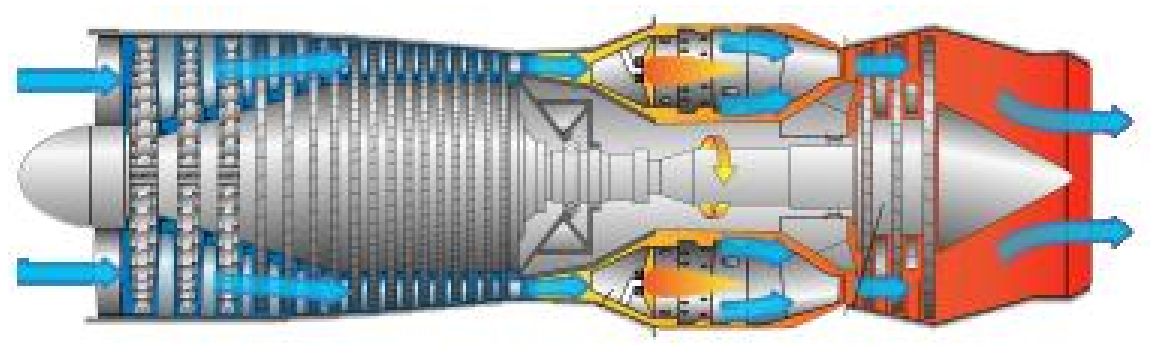

Figure 1 - Cross-section of a turbojet engine ( Dahl,. 2008)

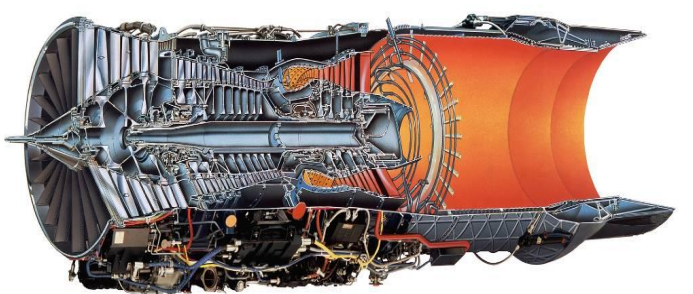

Figure 2 - By-pass engine with a low by-pass ratio (Letecký motor)

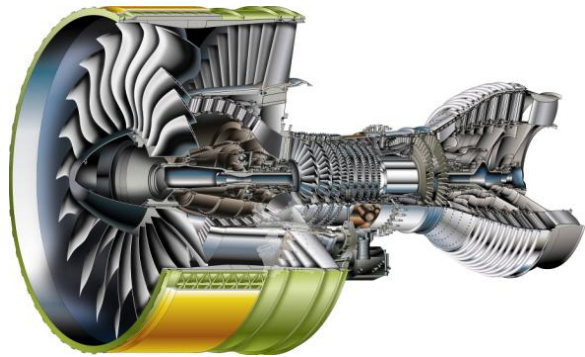

Figure 3 - Turbofan engine (Airbus A380)

The turbojet engines, i.e. the jet engines without a bypass, are distinguished by one compact stream of a gaseous medium flowing through the engine. Therefore they are typical by a "slim" cylindrical shape of external shell (Figure 1). In the case of the by-pass engines the stream of compressed air is divided onto an external flow - cold flow (or by-pass air) and internal flow - hot flow behind the compressor. According to the ratio of external and internal flow capacity there are known the bypass engines with a low (Figure 2) and a high (Figure 3) bypass ratio. There is also a special category of jet engines, namely the turbo-prop engines, Figure 4, specified for propeller aircrafts and the turbo-shaft engines, for driving of helicopters. 


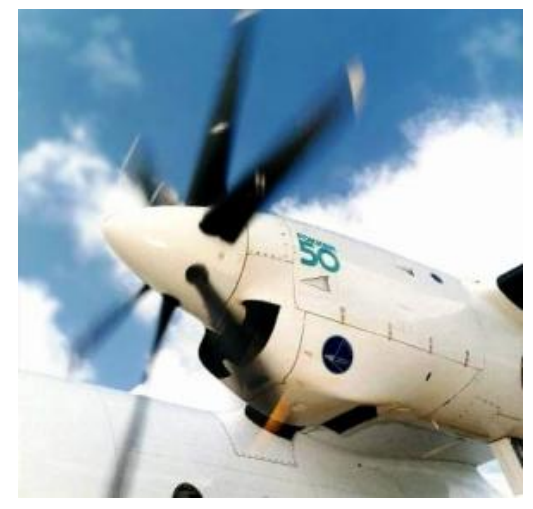

Figure 4 - View on turbo-prop engine (Fokker 50 Engines)

\subsection{Air-traffic emissions}

There are two main emission categories of the jet engines: noise emissions and gaseous emissions. They are related each other with regard to theoreticalprincipal aspects and taking into consideration construction-operational point of view of the jet-engine operation.

While the noise of jet engines is perceived immediately and in the surroundings of airports especially, the gaseous emissions, which are caused by these propulsive units, are not so evident. The exhaust gases from the aircraft engines are accumulating in the atmosphere during a longer time period and they are reaching also the upper atmospheric layers, because of standard flight levels of jet airliners, i.e. it concerns high flight levels, ranging from about $8000 \mathrm{~m}$ up to almost $13000 \mathrm{~m}$.

However, it is necessary to say that the fuel consumption of air transport participates only with $5 \%$ on the worldwide consumption of oil fuels (Sedláček, 2000). The specific fuel consumption of modern long haul aircrafts is less than in the individual motorcar traffic section or it is comparable fully with this, Table 1.

This fact can be illustrated by means of a simple calculation of specific fuel consumption, which is performed, for example, in the case of modern versions of the world wide popular Boeing B-737 powered by the high bypass ratio engines, Figure5. This plane is able to exploit one litre of kerosene (the aviation fuel of jet engines) for transport of about 25 passengers to the distance of $1 \mathrm{~km}$, what means a consumption of 4 litres per 1 passenger and per $100 \mathrm{~km}$. This specific fuel consumption corresponds to a standard passenger motorcar. This favourable result is typical just for the turbofan engines. The higher the bypass ratio value of the by-pass engine is, the more favourable is its specific fuel consumption.

The most serious harmful pollutants occurring in the jet engine gaseous emissions are: nitrogen oxides $\left(\mathbf{N O}_{\mathbf{X}}\right)$, hydrocarbons $(\mathbf{H C})$, carbon monoxide (CO) and sulphur dioxide $\left(\mathbf{S O}_{2}\right)$. The environmental impacts of the abovementioned substances are well known. 
Table 1 - Comparison of specific energy consumption in passenger traffic (Sedláček, 2000)

\begin{tabular}{|c|c|}
\hline $\begin{array}{c}\text { Passenger } \\
\text { Traffic }\end{array}$ & $\begin{array}{c}\text { Specific Energy } \\
\text { Consumption } \\
{[\mathrm{kJ} / \text { person } \cdot \mathrm{km}]}\end{array}$ \\
\hline Automotive & 2500 \\
\hline Air & 2100 \\
\hline Railway & 1300 \\
\hline Bus & 700 \\
\hline
\end{tabular}

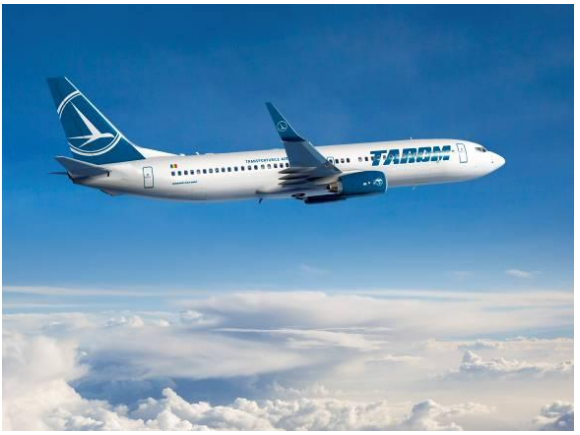

Figure 5-Boeing B-737 with turbofan engines (Tarom)

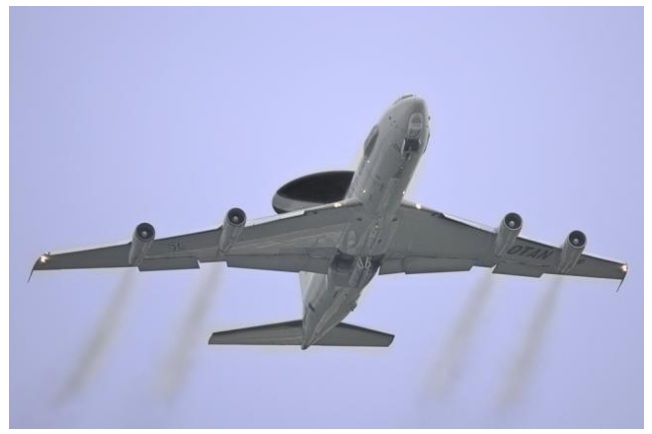

Figure 6-Smoke trails ("FotoFetischistin”, 2010)

Chemical structure of the exhaust gases is changing according to the various operational regime of the jet engine, Fig.7.

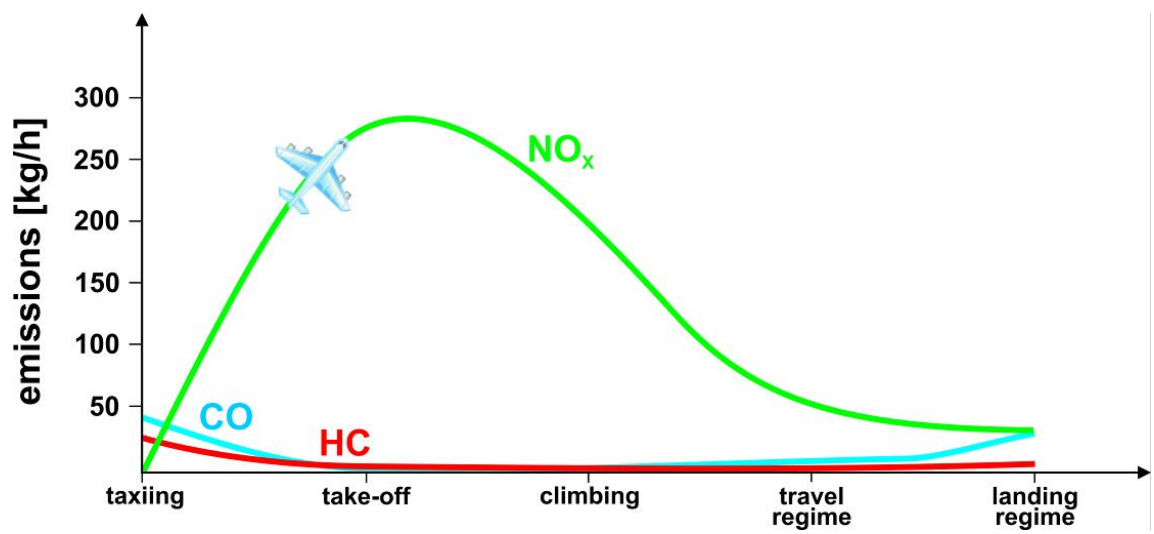

Figure 7 - Production of harmful pollutants during various jet engine working regimes (Kerner, Kulčák, and Sýkora, 2003) 
Production of the $\mathbf{N O}_{\mathbf{X}}$ is typical for a high thrust regime of power unit, namely during take-off and climbing phase of flight. The unburned hydrocarbons HC and $\mathbf{C O}$ are characteristic for a low level of thrust, especially during idling operational regime aground or when a plane is taxiing. The amount of $\mathbf{S O}_{2}$ consists in quality of fuel, namely on amount of sulphur.

There is also another phenomenon occurring during jet engine operation: it is production of smoke emissions. The burning process in combustion chamber is a complicated procedure because of mixing of the flowing air with the injected fuel. The main task of the combustion chamber is to create a correct mixture "fuel-air" and to burn it perfectly. However, if this process is not balanced well, the fuel is not mixed with air ideally, so that small fuel drops are carbonised inside of the combustion chamber on its internal shell. This incorrect (or imperfect) combustion regime results in creation of undesirable smoke trails visible like a track behind the flying plane, Figure 6 .

Technical improvements and innovations of jet engines during the last decades have been resulting also in a positive environmental impact presented in a form of a significant reduction of the most serious harmful pollutants occurring in gaseous emissions (Daneshjo, 2009).

\section{INNOVATIVE MEASURES ACTUAL FOR REDUCTION OF JET ENGINE GASEOUS EMISSIONS}

The modern aircraft engines are the top engineering products with excellent technical parameters. That is why environmental impacts of them are reduced and minimized. If we are thinking about possibilities how to reduce the jet engine gaseous emissions anywise, there are still three practicable ways, how to do it (Kerner, Kulčák, and Sýkora, 2003):

a) Technical measures are related to a high quality of the aviation fuel kerosene, as well as they are concerning application of the high quality materials and components used in the jet engine design and production.

b) Operational measures are focused on optimisation of operating procedures during take-off and landing phase of flight. The second important task in this area is a "logistical" improvement of airplane movements during taxiing in order to reduce idling times, as well as the long taxiing distances. Another achievement is a fact that the modern planes are equipped with computerised systems that are able to calculate an optimal amount of fuel, which has to be refuelled for the given flight and therefore in this way the fuel consumption is also reduced. This innovation is an example of a unique combination of economical and ecological advantages.

c) Development measures depend on technological progress in the process of jet engine development and production. This is a question addressed to the jet engine designers. However, in these days any possible future reduction of 
gaseous emissions of aircraft engines is a complicated task, taking into consideration the present "state of the art" level in this technical area.

\section{CONCLUSION}

The dynamic growth of modern air traffic would be unthinkable without a standard utilization of the reliable and cost-effective jet engines. The unprecedented boom of travelling by planes during the last decades was able thanks to application of jet engines with outstanding technical and operational parameters, especially thanks to combination of a high output engine thrust with low-level of specific fuel consumption (Hünecke, 2003). All the abovementioned facts presented in this paper are demonstrating an environmentalfriendly status of aircraft jet engines, which has been reached during the last decades by virtue of innovative technical solutions in the area of aircraft jet engines. This is the most important step in order to improve quality of passenger air traffic. This statement is presented and declared officially by leading professionals who act in the branch of modern air traffic (Eden, 2006).

\section{REFERENCES}

Airbus A380 Engine Cutaway gp7000 n.d. [image online] Available at: http://free-hdwallpapers.com/wallpapers/aircraft/13787.jpg

Dahl, J. 2008, Jet engine numbered [image online] Available at:

http://sk.wikipedia.org/wiki/S\%C3\%BAbor:Jet_engine_numbered.svg

Daneshjo, N. (2009). "Od myšlienky ku skutočnosti priemyselného dizajnu." Acta Mechanica Slovaca, Vol. 13, No 2-A, pp. 41-46, ISSN 1335-2393.

Eden, P. (2006). Moderne Verkehrsflugzeuge, Stuttgart: Motorbuch Verlag, 192 p., ISBN-10 3613305453.

Fokker 50 Engines n.d. [image online] Available at:

http://editor.stork.com/Stork/5724/F50_Engines.html

"Foto-Fetischistin" (2010). Boeing B707-300 E-3A Sentry AWACS [image

online] Available at: http://img.fotocommunity.com/images/Luft-und-

Raumfahrt/Militaerfliegerei/Boeing-B707-300-E-3A-Sentry-AWACSa23059067.jpg

Hünecke, K. (2003). Jet Engines: Fundamentals of Theory, Design and Operation, Osceola: Motorbooks International Publishers\&Wholesalers, USA, 251 p., ISBN 0-7603-0459-9.

Kerner, L.; - Kulčák, L. - Sýkora, V. (2003), Provozni aspekty letišst. Praha: Vydavatelství ČVUT, 270 p., ISBN 80-01-02841-0.

Kocáb, J., - Adamec, J. (2000), Letadlové motory, Praha: Kant cz s.r.o., 176 p., ISBN 80-902914-0-6. 
Letecký motor s prídavným spal'ovaním n.d. [image online] Available at: http://www.cfd.sk/tps/img1825.png

Pauliková, A. - Kopas, M. (2011). "Environmental consideration of air- traffic with regard to gaseous emissions", In: Development of Environmental Engineering Education: $2^{\text {nd }}$ International Conference, Slovakia, Košice: Elfa, pp. 113-115., ISBN 978-80-8086-185-8.

Sedláček, B. (2000). Letecká doprava, Žilina: Žilinská univerzita, 189 p., ISBN 80-7100-674-2.

Tarom primeste a treia aeronava Bboeing 737-800 Generation n.d. [image online] Available at: http://www.mediafax.ro/economic/tarom-primeste-a-treiaaeronava-boeing-737-800-generation-3795161

\section{ABOUT THE AUTHORS}

Assoc. prof. M.Sc. Alena Pauliková, Ph.D; Technical University of Košice, Faculty of Mechanical Engineering, Department of Environmentalistics, Park Komenského 5, 04187 Košice, the Slovak Republic, e-mail: alena.paulikova@tuke.sk

M.Sc. Melichar Kopas, Ph.D; Technical University of Košice, Faculty of Mechanical Engineering, Department of Machine Design, Transport and Logistics, Letná 9, 04200 Košice, Slovak Republic, email: melichar.kopas@tuke.sk 